\title{
Pengaruh Penerapan Strategi Pembelajaran Scaffolding terhadap Kemampuan Pemahaman Konsep Matematis Siswa Madrasah Tsanawiyah Al-Hidayah Singingi Hilir ditinjau dari Motivasi Belajar Siswa
}

\author{
Saputri Indah Lestari ${ }^{1}$ dan Lies Andriani ${ }^{2}$ \\ 1,2 Mathematics Education Departement, Universitas Islam Negeri Sultan Syarif Kasim Riau \\ e-mail: lies.andriani@uin-suska.ac.id
}

\begin{abstract}
ABSTRAK. Penelitian ini dilatarbelakangi oleh adanya permasalahan di lapangan yang menunjukkan bahwasanya kemampuan pemahaman konsep matematis siswa MTs Al-Hidayah Singingi Hilir yang masih tergolong rendah. Salah satu alternatif strategi pembelajaran yang diharapkan dapat mengarahkan siswa untuk meningkatkan kemampuan pemahaman konsep matematis adalah strategi pembelajaran scaffolding. Adapun penelitian ini bertujuan untuk menyelidiki ada tidaknya perbedaan kemampuan pemahaman konsep matematis antara siswa yang mengikuti strategi pembelajaran scaffolding dengan siswa yang mengikuti pembelajaran yang diterapkan guru berdasarkan motivasi belajar siswa MTs Al-Hidayah Singingi Hilir. Penelitian ini merupakan penelitian Quasi Experiment dan desain yang digunakan adalah Nonequivalent Posttest-Only Control Group Design. Populasi dalam penelitian ini adalah seluruh siswa kelas VIII MTs Al-Hidayah Singingi Hilir. Sampel penelitian ini dipilih dengan menggunakan teknik Sampling Purposive, terpilih kelas VIII.B sebagai kelas eksperimen yang diberikan strategi pembelajaran scaffolding, dan kelas VIII.A sebagai kelas kontrol yang diberikan pembelajaran yang diterapkan guru. Teknik pengumpulan data yang digunakan adalah tes dan angket dengan instrumennya adalah tes uraian untuk mengukur kemampuan pemahaman konsep matematis siswa dan angket untuk mengukur motivasi belajar siswa. Teknik analisis data yang digunakan dalam penelitian ini adalah anova dua arah (two way anova). Berdasarkan hasil analisis data dapat disimpulkan bahwa: 1) Terdapat perbedaan kemampuan pemahaman konsep matematis siswa yang mengikuti pembelajaran scaffolding dengan siswa yang tidak mengikuti pembelajaran scaffolding.; 2) Tidak terdapat interaksi antara strategi pembelajaran scaffolding dengan motivasi belajar siswa terhadap kemampuan pemahaman konsep matematis siswa.
\end{abstract}

Keywords : scaffolding, kemampuan pemahaman konsep matematis, motivasi belajar, dan quasi experiment.

\section{PENDAHULUAN}

Di dalam pembelajaran matematika pemahaman konsep merupakan salah satu aspek terpenting. Hal ini karena materi matematika yang bersifat terstruktur dan saling berhubungan antara materi satu dengan materi yang lainnya. Siswa dituntut agar mampu memahami hubungan antar konsep matematika. Dengan kata lain, ketidaktuntasan dalam memahami konsep prasyarat secara potensial akan menimbulkan kesulitan bagi siswa dalam mempelajari konsep-konsep selanjutnya yang akan berdampak pada hasil belajar matematika yang diperoleh siswa.

Sebagaimana yang tertuang dalam Peraturan Menteri Pendidikan Nasional RI Nomor 59 tahun 2014 menjelaskan bahwa salah satu tujuan pembelajaran Matematika di sekolah ialah agar siswa memiliki kemampuan memahami konsep matematika, menjelaskan keterkaitan antara 
konsep dan mengaplikasikan konsep atau algoritma, secara luwes, akurat, efisien dan tepat dalam pemecahan masalah.

Berdasarkan tujuan pembelajaran matematika yang dikemukakan tersebut, terlihat bahwa pemahaman konsep merupakan salah satu tujuan yang mendasar dalam pembelajaran matematika. Dalam hal ini Nasution menyatakan bahwa apabila siswa memahami suatu konsep, maka ia akan dapat menggeneralisasikannya dalam berbagai situasi lainnya (S. Nasution, 2000). Menurut Mas'ud Zein dan Darto (2017), pemahaman merupakan kemampuan untuk menangkap arti materi pelajaran yang dapat berupa kata, angka, menjelaskan sebab akibat). Menurut Ali Hamzah dan Muhlisrarini (2014), konsep adalah ide abstrak yang memungkinkan orang dapat mengklasifikasikan objek-objek atau peristiwa-peristiwa dan menentukan apakah objek atau peristiwa itu merupakan contoh atau bukan contoh dari ide abstrak tersebut.

Adapun indikator pemahaman konsep matematik dalam Kurikulum 2013 yang dikutip dari Heris Hendriana dkk (2017), yaitu: 1) Menyatakan ulang konsep yang telah dipelajari, 2) Mengklasifikasi objek-objek berdasarkan dipenuhi tidaknya persyaratan yang membentuk konsep tersebut, 3) Mengidentifikasi sifat-sifat operasi atau konsep, 4) Menerapkan konsep secara logis, 5) Memberikan contoh atau contoh kontra (lawan contoh) dari konsep yang dipelajari, 6) Menyajikan konsep dalam berbagai macam bentuk representasi matematis (tabel, grafik, diagram, sketsa, model matematika atau cara lainnya), 7) Mengaitkan berbagai konsep dalam matematika maupun di luar matematika, 8) Mengembangkan syarat perlu dan/tidak syarat cukup suatu konsep.

Namun, dari beberapa penelitian yang telah dilakukan terlihat bahwa kemampuan pemahaman konsep dan motivasi belajar matematika siswa masih terbilang rendah. Salah satunya penelitian yang dilakukan oleh Sutarto Hadi dan Maidatina Umi Kalsum diketahui bahwa hasil analisis kerja UTS matematika siswa kelas VII di salah satu sekolah di Martapura tahun 2015, kurang dari 50 \% siswa belum memenuhi Kriteria Ketuntasan Minimal (KKM). Hal ini disebabkan masih lemahnya pemahaman konsep matematika siswa dalam memahami soal.

Berdasarkan hasil wawancara yang dilakukan peneliti dengan guru matematika dan hasil ulangan harian siswa pada materi pola bilangan, bahwasanya kemampuan pemahaman konsep siswa MTs Al-Hidayah Singingi Hilir masih tergolong rendah. Hal ini terlihat dari masih banyaknya siswa yang belum mampu menemukan apa yang menjadi permasalahan dalam soal, sebagian besar siswa tidak dapat menyelesaikan soal yang berbeda dari contoh yang telah diberikan, sebagian siswa belum mampu menjelaskan kembali tentang konsep materi pembelajaran yang telah dipelajari, dan sebagian siswa hanya menyalin jawaban temannya tanpa memahami soal yang telah diberikan. Rendahnya kemampuan pemahaman konsep matematis siswa MTs Al-Hidayah Singingi Hilir juga terlihat dari data nilai ulangan harian siswa pada materi pola bilangan di kelas VIII. Dari empat soal yang mencakup soal pemahaman konsep dengan rata-rata siswa dalam satu kelas sebanyak 32 orang siswa, namun dari setiap kelas hanya sekitar sebelas sampai tiga belas orang siswa yang mendapat nilai diatas KKM (Kriteria Ketuntasan Maksimal) yang telah ditetapkan yaitu 74 .

Dari permasalahan-permasalahan yang telah dikemukakan, salah satu alternatif strategi pembelajaran yang diharapkan dapat mengarahkan siswa pada kemampuan pemahaman konsep matematis adalah strategi pembelajaran scaffolding. Istilah scaffolding digunakan oleh Wood dalam Asri Budiningsih (2012), dengan pengertian "dukungan pembelajar kepada peserta didik untuk membantunya menyelesaikan proses belajar yang tidak dapat diselesaikannya sendiri". Menurut Vygotsky, siswa mengembangkan keterampilan berpikir tingkat yang lebih tinggi ketika mendapat bimbingan (scaffolding) dari seorang yang lebih ahli atau melalui teman sejawat yang memiliki kemampuan lebih tinggi. Hal yang utama dalam penerapan scaffolding terletak pada bimbingan guru. Bimbingan guru diberikan secara bertahap setelah siswa diberi permasalahan, sehingga kemampuan aktualnya mencapai kemampuan potensial. Bantuan tersebut dapat berupa petunjuk, 
dorongan, peringatan, menguraikan masalah ke dalam langkah-langkah pemecahan, atau memberikan contoh (Agus N Cahyo, 2013).

Selain aspek kognitif yang menjadi tujuan pembelajaran, aspek afektif juga perlu diperhatikan. Salah satu aspek afektif yang dimaksud antara lain adalah motivasi belajar siswa. Motivasi adalah perubahan energi dalam diri sesorang yang ditandai dengan timbulnya perasaan dan reaksi untuk mencapai tujuan (Martinis Yamin, 2010). Dalam pembelajaran, adanya motivasi membangkitkan siswa untuk semangat mengikuti proses pembelajaran sehingga tercapailah tujuan pembelajaran tersebut. Adapun indikator motivasi belajar menurut Sardiman yang dinyatakan oleh Karunia Eka Lestari Mokhammad Ridwan Yudhanegara (2017) yaitu :1) Adanya dorongan dan kebutuhan belajar, 2) Menujukkan perhatian dan minat terhadap tugas-tugas yang diberikan, 3) Tekun menghadapi tugas, 4) Ulet menghadapi kesulitan, 5) Adanya hasrat dan keinginan berhasil. Berdasarkan latar belakang yang telah diuraikan, maka penulis tertarik untuk melakukan penelitian dengan judul "Pengaruh Penerapan Strategi Pembelajaran Scaffolding Terhadap Kemampuan Pemahaman Konsep Matematis Siswa MTs Al Hidayah Singingi Hilir ditinjau dari Motivasi Belajar Siswa".

\section{METODE PENELITIAN}

Penelitian ini dilaksanakan di kelas VIII MTs Al-Hidayah Singingi Hilir yang beralamat di jalan Merdeka desa Sukamaju kabupaten kuantan singingi kecamatam singingi hilir pada tahun 2018/2019 semester ganjil. Jenis penelitian yang dilaksanakan adalah penelitian Quasi Experiment. Dimana kelompok kontrol tidak berfungsi sepenuhnya untuk mengontrol variabel-variabel luar yang mempengaruhi pelaksanaan eksperimen (Sugiyono, 2012). Dengan desain yang digunakan adalah Nonequivalent Posttest-Only Control Group Design. Pada desain ini terdapat dua kelompok, kelompok pertama diberi perlakuan dan kelompok yang lainnya tidak. Kelompok yang diberi perlakuan disebut kelompok eksperimen dan kelompok yang tidak diberi perlakuan disebut kelompok kontrol. Kemudian kedua kelompok diberi posttest (Karunia Eka Lestari dan Mokhammad Ridwan Yudhanegara, 2017).

Populasi dalam penelitian ini adalah seluruh siswa kelas VIII MTs Al-Hidayah Singingi Hilir yang terdiri dari empat kelas. Teknik pengambilan sampel yang digunakan dalam penelitian ini adalah teknik sampling purposive. Sampling purposive adalah teknik pengambilan sampel berdasarkan pertimbangan tertentu (Sugiyono, 2016). Variabel-variabel yang digunakan dalam penelitian ini terdapat tiga variabel, yakni variabel bebas (independent variabel), variabel terikat (dependent variabel), dan variabel moderator. Dimana varibel bebas (independent variabel), dalam penelitian ini adalah strategi pembelajaran scaffolding, variabel terikat (dependent variabel), adalah kemempuan pemahaman konsep matematis siswa dan variabel moderatornya adalah motivasi belajar siswa.

Teknik pengumpulan data yang digunakan dalam penelitian ini adalah sebagai berikut:

\section{Observasi}

Observasi merupakan kegiatan pemusatan perhatian terhadap suatu objek dengan menggunakan seluruh alat indra (Hartono, 2010). Observasi bertujuan untuk mengumpulkan data dengan melakukan penelitian langsung terhadap kondisi lingkungan objek penelitian yang mendukung kegiatan penelitian. Observasi dilakukan setiap kali tatap muka, dengan tujuan untuk mengamati kegiatan guru dan siswa dalam menerapkan strategi pembelajaran.

\section{Angket}

Angket adalah sejumlah pertanyaan tertulis yang diajukan untuk memperoleh informasi tentang aspek-aspek atau karakteristik yang melekat pada responden (Hartono, 2010). 


\section{Tes}

Tes merupakan instrumen alat ukur untuk mengumpulkan data dimana dalam memberikan respon atas pertanyaan dalam instrumen, siswa didorong untuk menunjukkan penampilan maksimalnya (Purwanto, 2014).

Instrumen yang digunakan pada penelitian ini adalah sebagai berikut:

\section{Lembar Observasi}

Pada penelitian ini observasi dilakukan dengan menggunakan lembar observasi. Lembar observasi digunakan untuk mengamati aktifitas siswa dan aktifitas guru dikelas eksperimen apakah sudah memenuhi langkah-langkah strategi pembelajaran scaffolding dan apakah sudah terlaksana dengan baik. Model lembar observasi pada penelitian ini menggunakan skala likert (Iqbal Hasan, 2014), seperti pada tabel 1 berikut:

Tabel 1. Skala Likert Lembar Observasi

\begin{tabular}{cc}
\hline Kriteria & Skor \\
\hline Terlaksana Dengan Baik & 4 \\
Terlaksana & 3 \\
Kurang Terlaksana & 2 \\
Tidak Terlaksana & 1 \\
\hline
\end{tabular}

\section{Angket}

Pada penelitian ini angket digunakan untuk mengukur motivasi belajar siswa, baik kelas eksperimen maupun kelas kontrol. Adapun pemberian skor untuk angket motivasi belajar siswa dengan menggunakan skala likert (Sabana, 2000) yakni sebagai berikut:

Tabel 2. Pedoman Penskoran Angket Motivasi Belajar Siswa

\begin{tabular}{cccccc}
\hline \multirow{2}{*}{$\begin{array}{c}\text { Jenis } \\
\text { Pernyataan }\end{array}$} & Selalu & Sering & $\begin{array}{c}\text { Kadang- } \\
\text { Kadang }\end{array}$ & Jarang & Tidak Pernah \\
\cline { 2 - 6 } & 5 & 4 & 3 & 2 & 1 \\
Positif & 1 & 2 & 3 & 4 & 5 \\
Negatif & & & &
\end{tabular}

\section{Soal Posttest}

Pada penelitian ini soat posttest berupa tes tertulis berbentuk uraian, dan penilaian kemampuan pemahaman konsep matematis siswa didasarkan pada rubik penskoran (Mas'ud Zein dan Darto, 2012) yang dapat dilihat pada tabel 3 berikut:

Tabel 3. Pedoman Penskoran Kemampuan Pemahaman Konsep Matematis

\begin{tabular}{|c|c|c|c|}
\hline Skor & Pemahaman Soal & Penyelesaian Soal & Menjawab Soal \\
\hline 0 & $\begin{array}{l}\text { Tidak ada usaha } \\
\text { memahami soal }\end{array}$ & Tidak ada usaha & $\begin{array}{l}\text { Tanpa jawab atau jawaban } \\
\text { salah yang diakibatkan } \\
\text { prosedur penyelesaian tidak } \\
\text { tepat }\end{array}$ \\
\hline 1 & $\begin{array}{l}\text { Salah interpretasi soal } \\
\text { secara keseluruhan }\end{array}$ & $\begin{array}{l}\text { Perencanaan penyelesaian } \\
\text { yang tidak sesuai }\end{array}$ & $\begin{array}{l}\text { Salah komputasi, tiada } \\
\text { pernyataan, jawab pelabelan } \\
\text { salah }\end{array}$ \\
\hline 2 & $\begin{array}{l}\text { Salah interpretasi sebagian } \\
\text { besar soal }\end{array}$ & $\begin{array}{l}\text { Sebagian prosedur benar } \\
\text { tetapi masih terdapat } \\
\text { kesalahan }\end{array}$ & Penyelesaian benar \\
\hline 3 & $\begin{array}{l}\text { Salah interpretasi pada } \\
\text { sebagian kecil soal }\end{array}$ & $\begin{array}{l}\text { Prosedur substansial benar, } \\
\text { tetapi masih terdapat } \\
\text { kesalahan }\end{array}$ & - \\
\hline \multirow[t]{2}{*}{4} & $\begin{array}{l}\text { Interpretasi soal benar } \\
\text { keseluruhan }\end{array}$ & $\begin{array}{l}\text { Prosedur penyelesaian tepat, } \\
\text { tanpa kesalahan aritmatika }\end{array}$ & - \\
\hline & Skor maksimal $=4$ & Skor maksimal $=4$ & Skor maksimal $=2$ \\
\hline
\end{tabular}


Soal posttest disusun dengan berpedoman pada kisi-kisi butir soal yang ditetapkan berdasarkan kompetensi dasar dan indikator pada materi yang akan diujikan. Soal posttet diberikan setelah perlakuan untuk mengukur ada atau tidaknya perubahan tingkat kemampuan pemahaman konsep matematis siswa.

\section{HASIL DAN PEMBAHASAN}

\section{Hasil}

\section{Data Hasil Angkte Motivasi Belajar Siswa}

Berdasarkan perhitungan yang telah dilakukan, diperoleh pengelompokan siswa dengan kriteria tinggi, sedang, dan rendah berdasarkan hasil motivasi belajar siswa sebagai berikut:

Tabel 4. Kriteria Pengelompokan Motivasi Belajar Siswa

\begin{tabular}{|c|c|}
\hline Kriteria Motivasi Belajar & Keterangan \\
\hline$x \geq 66,84$ & Tinggi \\
\hline $48,12<x<66,84$ & Sedang \\
\hline$x \leq 48,12$ & Rendah \\
\hline
\end{tabular}

Berdasarkan perhitungan yang telah dilakukan, diperoleh tabel 4 tentang kriteria pengelompokan motivasi belajar siswa. Dari hasil pengelompokan motivasi belajar siswa, diperoleh bahwa pada kelas eksperimen terdapat 5 siswa yang memiliki motivasi belajar matematika tinggi, 14 siswa memiliki motivasi belajar sedang dan 12 siswa memiliki motivasi belajar rendah. Sedangkan pada kelas kontrol terdapat 6 siswa yang memiliki motivasi belajar matematika tinggi, 16 siswa memiliki motivasi belajar sedang dan 10 siswa memiliki motivasi belajar rendah.

\section{Data Nilai Awal Siswa}

Sebelum peneliti menerapkan strategi pembelajaran scaffolding pada kelas eksperimen, terlebih dahulu peneliti melihat nilai awal terhadap dua kelas yang dipilih. Analisis data yang digunakan adalah uji-t, yang mana sebelum dilakukan uji-t terlebih dahulu dilakukan uji prasyarat yaitu data berdistribusi normal dan homogen. Perhatikan tabel 5 dibawah ini:

\begin{tabular}{cccc}
\multicolumn{2}{c}{ Tabel 5 Hasil Uji Normalitas Nilai Awal Siswa } \\
\hline Kelas & $\boldsymbol{t}_{\boldsymbol{n}}$ & $\boldsymbol{t}_{\mathrm{t}_{\mathbf{i}}}$ & Keterangan \\
\hline Eksperimen & 11,02 & 11,07 & Normal \\
Kontrol & 10,45 & 11,07 & Normal \\
\hline
\end{tabular}

Berdasarkan perhitungan yang telah dilakukan, diperoleh tabel 5 tentang hasil uji normalitas nilai awal siswa. Dari hasil perhitungan tersebut menunjukkan nilai awal siswa pada kelas eksperimen dan kelas kelas kontrol yang memiliki harga $t_{\text {nit }} \leq t_{t_{1}}$, dimana $t_{\text {nit }}$ pada kelas eksperimen adalah 11,02 dan pada kelas kontrol dengan $t_{\text {nit }}=10,45$. Dengan harga $t_{t_{1}}=11,07$, maka data nilai awal siswa pada kelas eksperimen dan kelas kontrol dapat disimpulkan berdistribusi normal karena memenuhi syarat $t_{\text {nit }} \leq t_{t_{1}} \quad$ atau $11,02<11,07$ pada kelas eksperimen dan 10,45 $<11,07$ pada kelas kontrol. Selanjutnya perhatikan tabel 6 berikut:

\begin{tabular}{ccc} 
Tabel 6. Hasil Uji Homogen Nilai Awal Siswa \\
\hline Nilai Varians & \multicolumn{2}{c}{ Kelas } \\
\cline { 2 - 3 } Sampel & Eksperimen & Kontrol \\
\cline { 2 - 3 }$S^{2}$ & 461,820 & 281,233 \\
$\mathrm{~N}$ & 31 & 32 \\
\hline
\end{tabular}


Dari tabel 6 diperoleh nilai $F_{\text {nit }}=\frac{V \quad b}{V \quad k}=\frac{4,8}{2,2}=1,64213$.

Berdasarkan perhitungan yang telah dilakukan, diperoleh tabel 6 tentang hasil uji homogenitas nilai awal siswa. Dari hasil perhitungan tersebut memperoleh harga $F_{\text {nit }}=$ 1,64213, dan dimana pada taraf signifikan $(u)=0,05$, diperoleh $F_{t_{1}}=1,84$. Karena harga $F_{\text {nit }} \leq F_{t_{1}} \quad$ atau $1,64213<1,84$, sehingga dapat disimpulkan bahwa kelas eksperimen dan kelas kontrol memiliki data yang homogen.

Setelah uji normalitas dan homogenitas dilakukan pada data awal maka selanjutnya dilakukan uji-t dengan hasil pada tabel 7 berikut:

Tabel 7. Hasil Uji-t Nilai Awal Siswa

\begin{tabular}{crcc}
\hline Kelas & Mean & $\boldsymbol{t}_{\boldsymbol{n}}$ & $\boldsymbol{t}_{\mathbf{t}_{\mathbf{1}}}$ \\
\hline Eksperimen & $\begin{array}{l}63,19 \\
62,66\end{array}$ & 0,11 & 1,989 \\
Kontrol & & & \\
\hline
\end{tabular}

Berdasarkan perhitungan yang telah dilakukan, diperoleh tabel 7 tentang hasil uji-t nilai awal siswa. Dari hasil perhitungan tersebut memperoleh harga $t_{\text {nit }}=0,11$ dan dimana pada taraf signifikan $5 \%$ diperoleh $t_{t_{1}}=1,989$. Karena harga $t_{\text {nit }} \leq t_{t_{1}}$ atau $0,11<1,989$, sehingga dapat disimpulkan bahwa, dua kelompok sampel yang dipilih tidak terdapat perbedaan kemampuan awal pemahaman konsep matematis antara kelas kelas eksperimen kelas kontrol yang signifikan, artinya kedua kelompok tersebut dapat digunakan sebagai sampel dalam penelitian.

\section{Data Rekapitulasi Uji Validitas, Reliabilitas, Daya Pembeda dan Indeks Kesukaran Soal Posttest}

Adapun hasil uji validitas, reliailitas, daya pembeda dan indeks kesukaran butir soal posttest kemampuan pemahaman konsep dapat dilihat pada tabel 8 berikut:

Tabel 8. Rekapitulasi Uji Validitas, Reliabilitas, Daya Pembeda dan Indeks Kesukaran

\begin{tabular}{|c|c|c|c|c|c|c|c|c|c|}
\hline \multirow{2}{*}{$\begin{array}{l}\text { No. } \\
\text { Butir } \\
\text { Soal }\end{array}$} & \multicolumn{2}{|c|}{ Validitas } & \multicolumn{2}{|c|}{ Reliabilitas } & \multicolumn{2}{|c|}{ Daya Pembeda } & \multicolumn{2}{|c|}{$\begin{array}{c}\text { Indeks } \\
\text { Kesukaran }\end{array}$} & \multirow{2}{*}{ Keterangan } \\
\hline & $t_{n}$ & Kriteria & $r_{1}$ & Kriteria & $\boldsymbol{D}$ & Kriteria & $\boldsymbol{L}$ & Kriteria & \\
\hline 1 & 4,46 & Valid & \multirow{8}{*}{1,08} & \multirow{8}{*}{$\begin{array}{l}\text { Sangat } \\
\text { Baik }\end{array}$} & 0,55 & Baik & 0,49 & Sedang & Digunakan \\
\hline 2 & 3,00 & Valid & & & 0,32 & Cukup & 0,79 & Mudah & Digunakan \\
\hline 3 & 3,03 & Valid & & & 0,30 & Cukup & 0.87 & Mudah & Digunakan \\
\hline 4 & 3,02 & Valid & & & 0,22 & Cukup & 0,28 & Sukar & Digunakan \\
\hline 5 & 4,88 & Valid & & & 0,28 & Cukup & 0,78 & Mudah & Digunakan \\
\hline 6 & 2,04 & Valid & & & 0,23 & Cukup & 0,70 & Mudah & Digunakan \\
\hline 7 & 3,13 & Valid & & & 0,22 & Cukup & 0,76 & Mudah & Digunakan \\
\hline 8 & 3,55 & Valid & & & 0,50 & Baik & 0,58 & Sedang & Digunakan \\
\hline
\end{tabular}

\section{Data Hasil Posttest}

Analisis data posttest ini menggunakan anova dua arah, yang mana sebelum dilakukan anova dua arah terlebih dahulu dilakukan uji prasyarat yaitu data berdistribusi normal dan homogen. Hasil uji normalitas dapat dilihat pada tabel 9 berikut: 
Tabel 9. Hasil Uji Normalitas Soal Posttest

\begin{tabular}{cccc}
\hline Kelas & $\boldsymbol{x}_{\boldsymbol{h}}^{\mathbf{z}}$ & $\boldsymbol{x}_{\boldsymbol{i}}^{\mathbf{z}}$ & Keterangan \\
\hline Eksperimen & 5,504 & \multirow{2}{*}{11,07} & $\begin{array}{c}\text { Berdistribusi } \\
\text { normal }\end{array}$ \\
Kontrol & 9,382 & & \\
\hline
\end{tabular}

Berdasarkan perhitungan yang telah dilakukan, diperoleh tabel 9 tentang hasil uji normalitas soal posttest. Dari hasil perhitungan tersebut menunjukkan hasil soal posttest pada kelas eksperimen dan kelas kelas kontrol yang memiliki harga $x_{\text {nit }}^{2} \leq x_{t i}^{2}$, dimana $x_{\text {nit }}^{2}$ pada kelas eksperimen adalah 5,504 dan 9,382 pada kelas kontrol. Dengan $x_{t_{1}}^{2}$ pada taraf signifikan $(u)=0,05$, diperoleh harga $x_{t, 0}^{2}=11,07$, maka data soal posttest pada kelas eksperimen dan kelas kontrol dapat disimpulkan berdistribusi normal karena memenuhi syarat $x_{\text {nit }}^{2} \leq x_{t i}^{2}$ atau $5,504<11,07$ pada kelas eksperimen dan 9,382 $<11,07$ pada kelas kontrol. Sedangkan uji homogenitas data posttest dapat dilihat pada tabel 10 berikut:

\begin{tabular}{lrcr}
\multicolumn{2}{c}{ Tabel 10. Hasil Uji Homogenitas Soal Posttest } \\
\hline \multicolumn{1}{c}{ Kelas } & F $_{\text {hitung }}$ & F $_{\text {tabel }}$ & Keterangan \\
\hline $\begin{array}{l}\text { Eksperimen } \\
\text { Kontrol }\end{array}$ & 1,74 & 1,84 & Homogen \\
\hline
\end{tabular}

Dari tabel 10 diperoleh nilai $F_{\text {nit }}=\frac{v \quad b}{V \quad \frac{k}{, 0}}=\frac{2,3}{1,3}=1,74171$

Berdasarkan perhitungan yang telah dilakukan, diperoleh tabel 10 tentang hasil uji homogenitas soal posttest. Dari hasil perhitungan tersebut memperoleh harga $F_{\text {nit }}=1,74171$, dan dimana pada taraf signifikan $(u)=0,05$, diperoleh $F_{t_{1}}=1,84$. Karena harga $F_{\text {hit }} \leq$ $F_{t_{1}}$ atau $1,74171<1,84$, sehingga dapat disimpulkan bahwa kelas eksperimen dan kelas kontrol memiliki data posttest yang homogen.

Setelah uji normalitas dan homogenitas dilakukan pada data posttest maka selanjutnya dilakukan uji anova dua arah dengan hasil pada tabel 11 berikut:

Tabel 11. Hasil Uji Hipotesis Data Menggunakan Uji Anova Dua Arah

\begin{tabular}{cccccc}
\hline Sumber Varians & JK & dK & RJK & $\mathbf{F}_{\text {hitung }}$ & $\mathbf{F}_{\text {tabel }}$ \\
\hline Antara A & 625,440 & 1 & 625,440 & 4,016 & 4,01 \\
Interaksi AXB & 344,74 & 2 & 172,23 & 1,1059 & 3,15 \\
Dalam & 8876,9 & 57 & 155,74 & - & - \\
Total & 14327,71 & 62 & 231,09 & - & -
\end{tabular}

Berdasarkan perhitungan dengan menggunakan anova dua arah diperoleh:

1. Nilai $\mathrm{F}(\mathrm{A})_{\mathrm{h}} \geq \mathrm{F}(\mathrm{A})_{\mathrm{ti}}$, atau 4,016 $>4,01$ maka $\mathrm{H}_{0}$ ditolak sehingga dapat disimpulkan bahwa pada taraf kepercayaan 95\% terdapat perbedaan kemampuan pemahaman konsep matematis siswa yang mengikuti strategi pembelajaran scaffolding dengan siswa yang tidak mengikuti strategi pembelajaran scaffolding.

2. Nilai $\mathrm{F}(\mathrm{A} \times \mathrm{B})_{\mathrm{h}} \quad<\mathrm{F}(\mathrm{A} \times \mathrm{B})_{\mathrm{ti}}$, atau $1,1059<3,15$ maka $\mathrm{H}_{0}$ diterima sehingga dapat disimpulkan bahwa pada taraf kepercayaan 95\% Tidak terdapat interaksi antara strategi pembelajaran scaffolding dengan motivasi belajar siswa terhadap kemampuan pemahaman konsep matematis siswa. 


\section{PEMBAHASAN}

Hasil pengujian hipotesis $\mathrm{F}(\mathrm{A})_{\mathrm{h}} \quad \geq \mathrm{F}(\mathrm{A})_{\mathrm{ti}} \quad(4,016>4,01)$. Hal ini menunjukkan bahwa hipotesis $\left(\mathrm{H}_{0}\right)$ penelitian yang berbunyi "Tidak terdapat perbedaan kemampuan pemahaman konsep matematis siswa yang mengikuti pembelajaran Scaffolding dengan siswa yang tidak mengikuti pembelajaran scaffolding" ditolak. Sehingga hasil pengujian hipotesis menunjukkan bahwa terdapat perbedaan kemampuan pemahaman konsep matematis siswa yang mengikuti pembelajaran scaffolding dengan siswa yang tidak mengikuti pembelajaran scaffolding.

Perbedaan kemampuan pemahaman konsep matematis siswa juga terlihat dari perbedaan rata-rata nilai posttest siswa kelas eksperimen dan kelas kontrol yaitu 80,065 dan 69,093. Hal ini dikarenakan model pembelajaran scaffolding memberikan bantuan dan pengalaman belajar yang disesuaikan dengan kebutuhan siswa. Setiap siswa memiliki permasalahan belajar yang berbeda. Hal ini pula yang mendukung rumusan masalah yang diajukan yaitu terdapat perbedaan kemampuan pemahaman konsep matematis siswa yang mengikuti pembelajaran Scaffolding dengan siswa yang tidak mengikuti pembelajaran scaffolding.

Hal ini juga sejalan dengan hasil penelitian Nicke Septriani, dkk (2014) yang membuktikan bahwa penerapan strategi pembelajaran scaffolding dapat meningkatkan kemampuan pemahaman konsep matematis siswa, dan kemampuan pemahaman konsep matematika siswa yang belajar dengan strategi scaffolding lebih baik daripada kemampuan pemahaman konsep matematika siswa yang tidak mengikuti pembelajaran scaffolding.

Untuk melihat ada interaksi antara model pembelajaran scaffolding dengan motivasi belajar siswa dianalisis dengan anova dua arah dan diperoleh $\mathrm{F}_{\mathrm{h}}=1,1059$ dan $\mathrm{F}_{\mathrm{T}}=3,15$ sehingga $\mathrm{F}_{\mathrm{h}} \quad<\mathrm{F}_{\mathrm{ti}}$, atau $1,1059<3,15$. Berdasarkan hasil analisis dengan uji anova menunjukkan hipotesis $\left(\mathrm{H}_{0}\right)$ yang berbunyi "Tidak terdapat interaksi antara strategi pembelajaran scaffolding dengan motivasi belajar siswa terhadap kemampuan pemahaman konsep matematis siswa" diterima. Sehingga pada taraf kepercayaan 95\% tidak terdapat interaksi antara strategi pembelajaran scaffolding dengan motivasi belajar siswa terhadap kemampuan pemahaman konsep matematis siswa. Dengan demikian kamampuan pemahaman konsep matematis siswa karena strategi pembelajaran scaffolding tidak dipengaruhi oleh motivasi belajar siswa, sehingga tidak terdapat interaksi antara strategi pembelajaran scaffolding dengan motivasi belajar siswa terhadap kemampuan pemahaman konsep matematis siswa.

\section{KESIMPULAN}

Berdasarkan hasil penelitian yang telah diuraikan pada bab pembahasan maka dapat diambil kesimpulan bahwa penelitian dengan strategi pembelajaran scaffolding pada materi koordinat kartesius untuk memfasilitasi kemampuan pemahaman konsep matematis siswa Madrasah Tsanawiyah Al-Hidayah Singingi Hilir. Hal ini berarti bahwa rumusan masalah penelitian ini telah terjawab, yaitu sebagai berikut:

1. Terdapat perbedaan kemampuan pemahaman konsep matematis siswa yang mengikuti pembelajaran scaffolding dengan siswa yang mengikuti pembelajaran langsung di Madrasah Tsanawiyah Al-Hidayah Singingi Hilir. Analisis data dengan menggunakan uji anova dua arah menunjukkan nilai $F_{\text {nit }} \quad>F_{t_{\square}} \quad$ yaitu 4,016>4,01 yang berarti $H_{u}$ diterima dan $H_{\square}$ ditolak. Perbedaan tersebut diperkuat lagi dari mean yang berbeda antara kelas eksperimen dan kelas kontrol, dimana mean kelas eksperimen dan mean kelas kontrol secara berturut-turut adalah 80,06 dan 69,09.Disimpulkan terdapat perbedaan yang signifikan kemampuan pemahaman konsep matematis siswa antara kelas eksperimen dan kelas kontrol. Setelah mengikuti pembelajaran menggunakan strategi pembelajaran scaffolding pada materi koordinat kartesius rata-rata nilai kelas eksperimen lebih tinggi dibandingkan dengan kelas kontrol. Hal ini 
menunjukan bahwa strategi pembelajaran scaffolding dapat memfasilitasi kemampuan pemahaman konsep matematis siswa di Madrasah Tsanawiyah Al-Hidayah Singingi Hilir pada kelas VIII-B.

2. Tidak terdapat interaksi antara strategi pembelajaran scaffolding dengan motivasi belajar siswa terhadap kemampuan pemahaman konsep matematis siswa. Hal ini dapat dilihat dari nilai $\mathrm{F}(\mathrm{A} \times \mathrm{B})_{\mathrm{h}}=1,1059$ dan $\mathrm{F}(\mathrm{A} \times \mathrm{B})_{\mathrm{ti}} \quad=3,15$ pada taraf kepercayaan $95 \%$. Dengan kesimpulan $\mathrm{F}(\mathrm{A} \times \mathrm{B})_{\mathrm{h}} \quad<\mathrm{F}(\mathrm{A} \times \mathrm{B})_{\mathrm{ti}}$ yaitu $1,1059<3,15$ maka yang berarti $\mathrm{H}_{0}$ diterima dan $\mathrm{H}_{\mathrm{a}}$ ditolak.

\section{REFERENSI}

Budiningsih, A. (2012). Belajar dan Pembelajaran. Jakarta: Rineka Cipta.

Cahyo, A, N. (2013). Panduan Aplikasi Teori-Teori Belajar Mengajar Teraktual dan terpopuler. Yogyakarta: DIVA Press.

Hadi, S., \& Kalsum, M, U. (2015). Pemahaman Konsep Matematika Siswa SMP Melalui Penerapan Model Pembelajaran Kooperatif tipe Memeriksa Berpasangan (Pair Checks). EDU-MAT Jurnal Pendidikan Matematika, 3(1), 59-66.

Hamzah, A., \& Muhlisrarini. (2014). Perencanaan dan Strategi Pembelajaran Matematika. Jakarta: Raja Grafindo.

Hartono. (2010). Analisis Item Intrumen. Pekanbaru: Zanafa Pulishing.

Hasan, I. (2014). Pokok-Pokok Materi Metodologi Penelitian dan Aplikasinya. Bogor: Ghalia Indonesia.

Hendriana, H., Rohaeti, E, E., \& Sumarmo, U. (2017). Hard Skills dan Soft Skills Matematika Siswa. Bandung: Refika Aditama.

Lestari, K, E. \& Yudhanegara, M, R. (2017). Penelitian Pendidikan Matematika. Bandung: Refika Aditama.

Nasution, S. (2000). Berbagai Pendekatan dalam Proses Belajar dan Mengajar. Jakarta: Bumi Askara.

Purwanto. (2014). Evaluasi Hasil Belajar. Yogyakarta: Pustaka Belajar

Sabana. (2000). Statistik Pendidikan. Bandung: Pustaka Setia.

Salinan Peraturan Menteri Pendidikan dan Kebudayaan Republik Indonesia. (2014). No. 59. Jakarta: Kementrian Pendidikan dan Olahraga.

Septriani, D., dkk. (2014). Pengaruh Penerapan Strategi Scaffolding Terhadap Kemampuan Pemahaman Konsep Matematika Siswa Kelas VIII SMP Pertiwi 2 Padang. Jurnal Pendidikan Matematika, 3(3), 17-21.

Sugiyono. (2016). Metode Penelitian Kuantitatif dan R\&D. Bandung: Alfabeta.

Yamin, M. (2010). Kiat Membelajarkan Siswa. Jakarta: Gaung Persada Press.

Zein, M., \& Darto. (2012). Evaluasi Pembelajaran Matematika. Pekanbaru: Daulat Riau. 